\title{
Nutritional and Organoleptic Evaluation of Traditional Fruit Wines of North East Brewed from Nora Bagori (Prunus domestica) and Amlakhi (Embilica officinalis)
}

\author{
Mamoni Das ${ }^{*}$, Madhumita Barooah ${ }^{2}$, Diganta Goswami ${ }^{2}$, Moloya Gogoi ${ }^{1}$ and \\ Susanta Sarmah Pathak ${ }^{3}$ \\ ${ }^{1}$ Department of Food Science and Nutrition, College of Home Science, \\ Assam Agricultural University, Jorhat -785013, India \\ ${ }^{2}$ Deparment of Agricultural Biotechnology, ${ }^{3}$ Department of Statistics, Biswanath, College of \\ Agriculture, Assam Agricultural University, Jorhat -785013, India \\ *Corresponding author
}

\begin{tabular}{|c|c|}
\hline \multicolumn{2}{|r|}{ A B S T R A C T } \\
\hline & \multirow{7}{*}{$\begin{array}{l}\text { Consumption of wide range of alcoholic beverages made from cereals and fruits is an } \\
\text { integral part of diverse ethnic communities residing in the North Eastern Region of India. } \\
\text { Fermented alcoholic beverages prepared in this region are unique and bear deep } \\
\text { attachment with socio-cultural lives of local people. Wines from nora bogori (Prunus } \\
\text { domestica) and amlakhi (Embilica officinalis) were prepared following the traditional } \\
\text { methods adopted by ethnic tribes of Assam. The developed wines were assessed for } \\
\text { physicochemical, nutritional and organoleptic properties using standard methods. Results } \\
\text { revealed that the alcohol percentage of the developed wines ranged between } 11.6 \text { to } \\
12.1 \% \text {, which was at par with the recommended specifications for commercial table wine. } \\
\text { The pH of nora bogori and amlakhi wines were } 3.3 \text { and } 3.4 \text { and the total acidity was } 1.12 \\
\text { and } 1.57 \text { respectively, which reflects stability of the developed wines. The iron content of } \\
\text { nora bogori wine was found to be } 0.174 \mathrm{mg} / 100 \mathrm{ml} \text { whereas in amlakhi wine was } 0.29 \\
\text { mg/100 ml. Calcium content was } 136 \mathrm{mg} \text { and } 392 \text { mg per } 100 \text { ml in nora bogori and } \\
\text { amlakhi wines respectively. Potassium content of nora bogori and amlakhi wines was } \\
1.3 \mathrm{mg} / 100 \mathrm{ml} \text { and } 4.60 \mathrm{mg} / 100 \mathrm{ml} \text { whereas the phosphorus content was found to be } 2.473 \\
\mathrm{mg} / 100 \mathrm{ml} \text { and } 3.679 \mathrm{mg} / 100 \mathrm{ml} \text { in nora bogori and amlakhi wine respectively. Sensory } \\
\text { evaluation of the nora bogori and amlakhi wine produced with traditional fermentation } \\
\text { conditions showed good quality and overall acceptability with high values for colour, } \\
\text { aroma, flavour, astringency and body. Our study recommends that traditional method of } \\
\text { wine brewing can benefit further scientific study to optimise the production and processing } \\
\text { and be adopted at commercial level to produce good quality wine. }\end{array}$} \\
\hline Keywo & \\
\hline & \\
\hline & \\
\hline Article Info & \\
\hline & \\
\hline & \\
\hline
\end{tabular}

\section{Introduction}

Brewing and consumption of wide range of alcoholic beverages is an integral part of more than 130 ethnic communities residing in the north-eastern region of India. The prevalence of a diverse agro-climatic condition in north east India has favoured a rich repository of horticultural and botanical diversity. The region is home to variety of fruits viz., citrus, 
plum including some indigenous fruits with their own unique taste, colour and medicinal properties. The ethnic communities of the region have an ancient tradition in fruit winemaking from the region's wide variety of wild and cultivated fruits. Fermented alcoholic beverages prepared in this region are unique and bear deep attachment with socio-cultural lives of local people. Fruit wines are undistilled alcoholic beverages made from fruits other than grapes. Such fruit wines prepared from different fruits like peaches, plums, apricots, banana, elderberry or blackcurrent are nutritive, tasty and mildly stimulant.

The fruits undergo a period of fermentation and ageing and usually have an alcohol content ranging between 5- $13 \%$. Fermentation has been used since time immemorial as an effective and low cost means to preserve the quality and safety of the fruits and vegetables. These products serve as a source of income to many rural people, who prepare them at home and market them locally. The traditional knowledge of brewing fruit wine warrants scientific study including, their documentation before they become extinct.

Detailed studies on nutritive and medicinal value of ethnically produced products are expected to provide valuable information and would prove beneficial in guiding the production of these products on a commercial scale. In this paper we report the preparation of fruit wines from nora bogori (Prunus domestica) and amlakhi (Embilica officinalis) using traditional brewing process and provide its detailed nutritional, physicochemical properties including its an assessment of its organoleptic acceptance. The present study aims to throw light on the traditional household wine making process as well as highlight the beneficial properties of indigenous fruit wines.

\section{Materials and Methods}

\section{Formulation of wines}

The wines were prepared in the laboratory following the traditional method adopted by the ethnic tribes of Assam and was kept in cellar (dark room) for two months. The mulled wine was filtered through muslin cloth and kept in clean glass bottle for ageing for a period of 6 months. (Fig $1 \& 2$ )

\section{Physicochemical analysis wine}

The nora bogori and amlakhi wine obtained were analyzed for the various physicochemical characteristics. Total Soluble Solids (TSS) content was estimated using Abbey's Refractometer. It is also expressed as ${ }^{\circ}$ Brix". pH was determined using digital $\mathrm{pH}$ meter.

Total acidity and volatile acidity were determined by acid base titration. The total mineral content, iron, calcium, potassium, sodium and reducing sugar contents were quantified by AOAC methods (AOAC, 2002).

\section{Organoleptic evaluation}

The sensory evaluation of wines of different treatments was conducted by a trained panel of 10 judges. Each judge was given a set of wines separately in isolated booths and provided with a glass of fresh water to rinse their mouth before tasting the next sample.

Each sample was evaluated for various quality attributes, viz. colour, consistency, aroma, overall acceptability using a 9 point Hedonic scale.

\section{Statistical analysis}

All the data were subjected for analysing the variance using SPSS 22.0 software and the 
difference between means were compared by t-Test: Paired Two Sample for Means $(\mathrm{P}<0.05)$.

\section{Results and Discussion}

\section{Physicochemical characteristics of developed wines}

The physicochemical characteristics of the developed wines are presented in Table 2 . The $\mathrm{pH}$ of the developed nora bogori and amlakhi wines were 3.3 and 3.5 and the total acidity 1.12 and 1.57 respectively, which reflects its stability. The amount of acids present in wine determines its quality. The sum total of acids determines the intensity of tartness of a wine. Low $\mathrm{pH}$ of 3.3 to 3.5 as found in the wine is a good indicator and it acts as a preservative and keeps the chemical reactions totally controlled (Manwar et al., 2013; Argade and Pande, 2016). A pH of above 4 may result in quick spoilage of the wine and become chemically unstable (Patel and Telange, 2011). Acidity plays a crucial role in imparting taste and flavour to the wine besides protecting the wine from spoilage (Sim and Morris, 1984). The titratable acidity and $\mathrm{pH}$ were found to be inversely related with each other's (Joshi and Sharma, 1993; Abrol and Joshi, 2011). Volatile acidity refers to the volatility of the acid with steam and is normally expressed in terms of acetic acid. It is a common practice to assess the volatile acid content of wine, as it is an indicator of the soundness of wine. The volatile acidity was $0.65 \%$ in nora bogori wine and $0.9 \%$ in amlakhi wine. These values were within the standard limits of Indian standard of wine constituent i.e. $1 \mathrm{gL}^{-1}$ as reported by Bhalerao (2001). High volatile acidity indicates acidification of wine.

The alcohol content at the end of fermentation (12.1\% in Nora Bogori and $11.60 \%$ in and Amlakhi wine) corresponds to the alcohol content of the wines, generally between 11 and $14 \%$ (Meillon, 2009). So wines from both nora bogori and amlakhi can be considered as Table wines.

Total soluble solids are an important factor in making quality wine. The final TSS of wines depends upon the utilization of sugars by the yeast cells. In the present investigation, the Total Soluble solids (TSS) in amlakhi wine was found to be $4.6 \%$ whereas the nora bogori wine had a TSS of $8.5 \%$.

Reduction in TSS is an indicator for the completion of fermentation process and is attributed to the higher ferment ability of juice which may be due to more availability of sugar in the initial stage (Nishino et al., 1985). Nora bogori and amlakhi wine had $2.2 \%$ and $1.9 \%$ reducing sugar. Low amount of reducing sugar indicates higher rate of fermentation.

Generally, soluble solids in fruit wines are closely related to sugar content, however, it does not represent the entire TSS concentration. Sugar contents, organic acids, nitrogen, inorganic nutrients, and ethanol contents as a whole influence a soluble solid content in fruit wines. In the fruitfermentation mixture, approximately 5\% of sugar is conversed to organic acids, such as glycerol, acetic, lactic, and succinic acid, $2.8 \%$ of sugar is utilized as a carbon source for growth of yeasts, and only $0.2 \%$ of sugar is remained in fruit wines finally. Therefore, approximately $92 \%$ of sugar is utilized for the ethanol fermentation (Kim et al., 2012).

\section{Nutritional composition of fruit wines}

The iron content in the wine is an important criteria for wine makers as high level of iron may cause cloudiness or change in colour. Amount of iron over 7-10 mg/L is generally associated with this haze formation (Amerine 
and Ough, 1974) and may accelerate oxidation.

In white wine, colloidal ferric phosphate precipitates to form a milky white opaqueness. In red wines, the precipitation of ferric tannate forms a blue black film.

Iron contamination occurs during storage in vessels from contact with fittings composed of iron or iron alloys (Amerine and Ough, 1974). In the present study, the iron content of nora bogori wine was found to be 0.174 $\mathrm{mg} / 100 \mathrm{ml}$ whereas in amlakhi wine it was $0.29 \mathrm{mg} / 100 \mathrm{ml}$. Low iron levels improves the clarity of wine. Iron is involved in the solubility and stability of certain protein fractions in wine. Alteration of the iron equilibrium in wine affects the solubility of the protein resulting in protein-metal hazes (Boulton et al., 1998).

Calcium content of nora bogori wine was 136 $\mathrm{mg}$ per $100 \mathrm{ml}$ whereas, the amlakhi wine had $392 \mathrm{mg}$ calcium per $100 \mathrm{ml}$. Increase $\mathrm{Ca}$ content indicates good nutritive value of the wine

This can be appreciated by consumers who are now more aware of nutritive benefits of what they consume. The calcium content in wine increased with aging (Josephine et al., 2014). The sodium content of nora bogori wine was $19 \mathrm{~m} \mathrm{~g} / 100 \mathrm{ml}$ and amlakhi wine was $10.5 \mathrm{mg} / 100 \mathrm{ml}$.

Fig.1 Flow chart of traditional method of wine making from Nora Bogori

Nora Bogori $(1 \mathrm{~kg})$

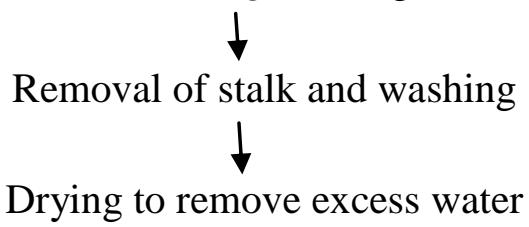

Filling the whole fruits in glass jars

Addition of sugar (500 g) +Starter culture (previous wine, $50 \mathrm{ml}$ )

Sealing of the bottles

Left for fermentation in dark room for

60 days at $30-35^{\circ} \mathrm{C}$

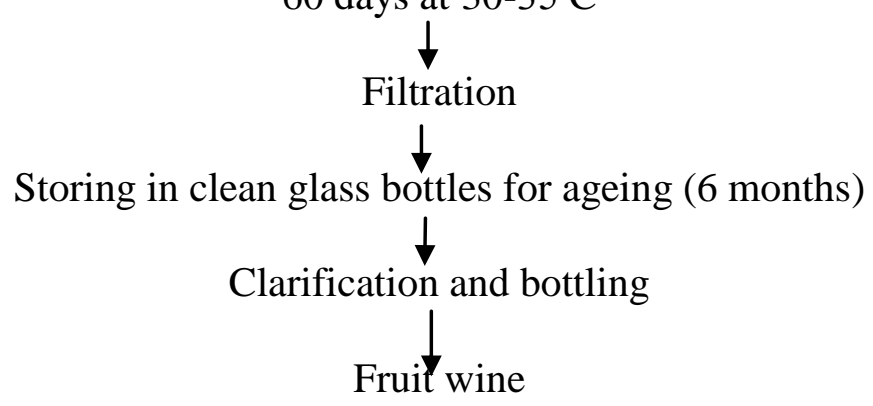


Fig.2 Flow chart of traditional method of wine making from Amlakhi

Amlakhi $(1 \mathrm{~kg})$

Removal of stalk and washing

Drying to remove excess water

Filling the whole fruits in glass jars

Addition of sugar $(650 \mathrm{~g})+$ Starter culture (previous wine, $50 \mathrm{ml}$ )

Sealing of the bottles

$\downarrow$

Left for fermentation in dark room for

60 days at $30-35^{\circ} \mathrm{C}$

Filtration

Storing in clean glass bottles for ageing (6 months)

Clarification and bottling

Fruit wine

Table.1 Physico chemical properties of Nora bogori and Amlakhi wine produced by traditional methods

\begin{tabular}{|l|c|c|}
\hline Parameters & Plum wine (\%) & Amla wine (\%) \\
\hline $\mathrm{pH}$ & 3.30 & 3.40 \\
\hline Total Acidity & 1.12 & 1.57 \\
\hline Volatile Acidity & 0.65 & 0.90 \\
\hline Alcohol Percentage & 12.1 & 11.60 \\
\hline TSS & 8.50 & 4.60 \\
\hline Reducing sugar & 2.20 & 1.90 \\
\hline
\end{tabular}

Table.2 Mineral content of Nora Bogori wine and Amlakhi wine produced by traditional methods (mg per $100 \mathrm{ml}$ )

\begin{tabular}{|l|c|c|}
\hline Nutrients & Nora Bogori wine & Amlakhi wine \\
\hline Iron & 0.174 & 0.29 \\
\hline Calcium & 136.00 & 392.00 \\
\hline Phosphorus & 2.473 & 3.679 \\
\hline Sodium & 19.00 & 10.50 \\
\hline Potassium & 13.0 & 46.00 \\
\hline
\end{tabular}


Table.3 Mean scores of Nora Bogori wine and Amla wine using 9 point Hedonic Scale

\begin{tabular}{|c|c|c|}
\hline Attributes & Nora Bogori wine & Amlakhi wine \\
\hline Colour & 9.0 & 8.5 \\
\hline Aroma & 8.5 & 9.0 \\
\hline Flavour & 8.5 & 8.0 \\
\hline Astringency & 8.5 & 8.0 \\
\hline Body & 9.0 & 8.5 \\
\hline Overall acceptability & 9.0 & 8.5 \\
\hline
\end{tabular}

*values are mean of panellists score

It has been reported that, in red wines, the abnormally and extremely high $\mathrm{Na}$ content indicates the possibility that $\mathrm{Na}$ was added in some red wines for prevention of potassium bitartarate-precipitation in a brewing procedure. As compared with potassium bitartarate in ethanol, sodium bitartarate is more soluble and causes less precipitation and stable colloids in ethanol, after bottling (Delfini and Formica, 2001; Jackson, 2008). So the sodium content in the developed traditional wines could contribute to the clarity of the wines. A study revealed that, sodium content was increased as wine ages. It could be mentioned that Sodium is a key player in heartbeat regulation and maintaining balanced blood pressure level. This may be the reason for moderate consumption of wine reduces the risk of cardiovascular disease (Creina, 2011).

The potassium content of nora bogori and amlakhi wine was $13.00 \mathrm{mg} / 100 \mathrm{ml}$ and $46.00 \mathrm{mg} / 100 \mathrm{ml}$ respectively. Similarly phosphorus content of nora bogori and amla wine was $2.4 \mathrm{mg} / 100 \mathrm{ml}$ and $3.67 \mathrm{mg} / 100 \mathrm{ml}$. Potassium ions are combined to tartaric acid, and form potassium bitartarate $\left(\mathrm{C}_{4} \mathrm{H}_{5} \mathrm{O}_{6} \mathrm{~K}\right)$.

The solubility of potassium bitartarate is high and is not precipitated easily in water, whereas it has low solubility and is precipitated in ethanol (Jackson, 2008). Phosphorus is another mineral which forms an important part of mineral matter of our skeleton. The phosphorus content of nora bogori wine was found to be $2.473 \mathrm{mg} / 100 \mathrm{ml}$ and amla wine was $3.679 \mathrm{mg} / 100 \mathrm{ml}$.

Sensory evaluation of the nora bogori and amlakhi wine produced with traditional fermentation conditions showed good quality and overall acceptability with high values for colour, aroma, flavour, astringency and body (Table 3).

The sensory analysis of wine is an important parameter in determining the quality of wines. It revolves around the taste, feel, aroma and bouquet of the aged wine. A number of methods in the form of hedonic scales and analytical techniques like GCMS have been developed (Amerine and Roessler 1976; Reynolds, 2010). So much is the importance of sensory evaluation that capturing consumers' mind and attitudes towards wines is a flourishing business (Lesschaeve, 2007). Shankar et al., (2006) highlighted the increase in aroma and flavour of guava wine with supplementation of $\mathrm{N}$ and $\mathrm{P}$ in the "must".

The wines were subjected to sensory evaluation where a panel of 10 semi trained panellist assessed its organoleptic characteristics. It was found that both the wines had high scores in terms of all the sensory attributes. The overall acceptability of nora bogori wine was 9 and for amlakhi wine was 8.5 , indicating high level of acceptability. High acceptability scores of these 
traditionally prepared wines, thus can be recommended for commercial production to serve as a special beverage.

The $\mathrm{t}$-Test revealed a significant difference in total acidity, volatile acidity, alcohol percentage and TSS at 5\% probability between the nora bogori wine (\%) and amlakhi wine (\%). However, when all the parameters and attributes were considered together, there was no significant difference between the nora bogori and amlakhi wine.

Consumption of fruit wine in moderation is reported to have a beneficial effect on the cardiovascular system as well as the general wellbeing of the consumers. Our study indicates that the nora bogori and amlakhi wines produced in this study using traditional methods have good nutritional quality and sensory acceptability. The north east India is home to several indigenous fruits that have remained underexploited due to the lack of awareness of their potential, market demand and value addition. The increasing popularity and acceptance of fruit wines has created an entirely new market for fruit wines. Our study recommends that traditional method of wine brewing can benefit further scientific study to optimise the production and processing and be adopted at commercial level to produce good quality wine. Such study can not only encourage the entrepreneurs to develop and upscale the existing cottage wineries in the Northeast India using the locally available fruits but also would enhance income of small and marginal farmers and also help in on-farm conservation of valuable germplasm of $\mathrm{NE}$ India.

\section{References}

Abrol, G.S., and Joshi, V.K. 2011. Effect of different initial TSS level on physicochemical and sensory quality of wild apricot mead. Internat. J. Food and
Ferm. Tech., 1 (2), 221-229.

Achaya, K.T., 1991. Alcoholic fermentation and its product in ancient India. Internat. J. History of Sci., 26: 123-129.

Amerine, M.A., and Ough, C.S. 1974. 'Wine and Must Analysis'. (John Wiley and Sons, Inc.: New York)

Amerine, M.A., and Roessler, E. B. 1976. Wines: Their Sensory Evaluation, M.A. Amerine and E.B. Roessler (Eds.), W.H. Freeman \& Co., New York.

AOAC, 2002. Official Methods of Analysis. (17th Edn). Association of Official Analytical Chemists. Washington, USA.

Argade, V.P., and Pande, V. V. 2016. Influence of different fermentation conditions on the formulation and development of Amla (Emblica officinalis Gaertin.) wine, Indian $J$. Traditional Knowledge. 15(2):254-259.

Bhalerao, S.B., 2001. Indian grape wine. A profitable business from grape cultivation (Trans) Drakshvritta, 27 (8): 73-78.

Boulton, R.B., Vernon, L.S., Bisson, L.F., and Kunkee, R.E. 1998. 'Principles and Practices of Winemaking'. (Aspen Publishers: Maryland).

Creina, S., Stockley. 2011. Therapeutic value of wine: A clinical and scientific perspective: A perspective. In: Handbook of Enology. Vol 1 (Ed. V. K. Joshi): Asia Tech Publishers, Inc. New Delhi. pp 146-208.

Das, A.J., Deka, S.C. and Miyaji, T. 2012. Methodology of rice beer preparation and various plant materials used in starter culture preparation by some tribal communities of North-East India: A survey. Internat. Food Res. Journal., 19: 101-107.

Delfini, C., and Formica, J.V. 2001. Wine technology: science and technology. NY, USA: Marcel Dekker, Inc.

Jackson, R.S., 2008. Wine science principles and applications, Third edn Elsevier: 
San Diego, CA, USA.

Josephine, N.M., Radhika, B. and Ganesan, T. 2014. Nutrient Analysis of Tomato Wine, International Journal of Innovative Science, Engineering \& Technology., 1(8):278-283.

Joshi, V.K., and Sharma, S.K. 1993. Effect of method of must preparation and initial sugar levels on the quality of apricot wine. J. Sci. \& Indus. Res., 39 (4), 255 257.

Joshi, V.K., Bhutani, V.P., Lal, B.B. and Sharma, R. 1990. A method for the preparation of wine from the wild apricot. Indian Food Packer., 44(5), 5055.

Kim, Y.J., Song, K.C., Lee, Y.H., Jang, K.H., Jung, S.T. and Jeong, C. 2012. Fruit wine: science and application. Gyeonggi-do, Korea: Ministry for Food, Agriculture, Forestry and Fisheries.

Lesschaeve, I., 2007. Sensory evaluation of wine and commercial realities: review of current practices and perspectives. Am. J. Eno. Viti, 58: 252-258.

Manwar, J., Kakasaheb, M., Anant, P., Sathiyanarayanan, L., Vohra, M. and Patil, S. 2013. Isolation, biochemical and genetic characterizations of alcoholproducing yeasts from the flowers of Woodfordia fruticose. J. Young Pharmacists, 5: 191-194.

Meillon, S., Urbano, C. and Schlich, P. 2009. Contribution of the temporal dominance of sensations (TDS) method to the sensory description of subtle differences in partially dealcoholized red wines. Food Qual. Preference., 20:490-499.

Nishino, H., Miyezaki, S. and Totojo, K. 1985. Effect of osmotic pressure on growth and fermentation activity of wine yeast. $J$ Enological. Vitic., 36: 170-174.

Patel, N.V., and Telange, DR. 2011. Qualitative and quantitative estimation of Gallic acid and Ascorbic acid in polyherbal tablets. Int. J. Pharmaceut Sci Res., 2(9): 2394-2398.

Reynolds, A.G., 2010. Managing wine quality. Vol 1. Viticulture and wine quality. Woodhead publishers, New York.

Shankar, S., Dilip, J., and Narayana, R.Y. 2006. Fermentation of guava pulp with grape grown yeast ( $S$. cerevisiae var. ellipsoideus) for wine production. Indian J. Hort., 60: 171-173.

Sim, C.A., and Morris, J.R. 1984. Effect of $\mathrm{pH}, \mathrm{SO}_{2}$, storage time and temperature on the colour and stability of red muscadine grape wine. Amer. J. Enol. Vitic, 35(1): 35-39.

Tanti, B., Gurung, L., Sarma, H.K. and Buragohain, A.K. 2010. Ethanobotany of starter culture used in alcohol fermentation by a few ethnic tribes of Northeast India. Indian. J. Traditional Knowledge. 9: 463- 466.

\section{How to cite this article:}

Mamoni Das, Madhumita Barooah, Diganta Goswami, Moloya Gogoi and Susanta Sarmah Pathak. 2017. Nutritional And Organoleptic Evaluation of Traditional Fruit Wines of North East Brewed from Nora Bagori (Prunus domestica) and Amlakhi (Embilica officinalis). Int.J.Curr.Microbiol.App.Sci. 6(9): 104-111. doi: https://doi.org/10.20546/ijcmas.2017.609.012 